DOI: $10.17951 / \operatorname{lrp} .2016 .35 .2 .55$

\author{
ANDRZEJ WĘGLIŃSKI \\ Uniwersytet Marii Curie-Skłodowskiej w Lublinie
}

\title{
AUTOPERCEPCJA BEZPOŚREDNICH ODDZIAŁYWAŃ WYCHOWAWCZYCH SPOŁECZNYCH KURATORÓW SĄDOWYCH
}

\begin{abstract}
Abstrakt: W artykule dokonano oceny sposobów wywierania wpływu wychowawczego społecznych kuratorów sądowych. Wprowadzenie teoretyczne zawiera krótką analizę mieszanego modelu kurateli sądowej dla dorosłych i uwarunkowań oddziaływań resocjalizacyjnych w pracy z osobami, u których przestępczość łączy się z czynnikami ryzyka i zaburzeniami związanymi z problemem alkoholowym. W części empirycznej zaprezentowano autopercepcję sposobów oddziaływań wychowawczych społecznych kuratorów sądowych. Przedstawione badania są unikalne na tle dotychczasowych, jednostronnych analiz pracy kuratorów opartych głównie na ocenie zapisów kart czynności wytwarzanych przez samych kuratorów.
\end{abstract}

Słowa kluczowe: probacja, dozorowani, metody wychowania

\section{WPROWADZENIE}

Kuratela ma w Polsce wieloletnią tradycję. Jej początki sięgają okresu międzywojennego. Wypracowane w okresie II Rzeczypospolitej modelowe rozwiązania określające usytuowanie, funkcje i zadania kuratorów sądowych okazały się bardzo trwałe. Rodzima kuratela od pełnienia szczególnej „obywatelskiej funkcji honorowej” zaczęła coraz bardziej przybliżać się do wykonywania zadań typowych dla „stróża prawa” i „sądowego policjanta”. Z uwagi na usytuowanie kuratorów w wydziałach karnych i rodzinnych sądu bardzo trudnym, a nawet wręcz niemożliwym zabiegiem jest ich porównanie ze służbami probacyjnymi funkcjonującymi w Anglii, Francji, Belgii czy Stanach Zjednoczonych. 
Tymczasem już pod koniec XIX wieku w metodycznych oddziaływaniach służb społecznych i probacyjnych na świecie można dostrzec pierwsze próby zastosowania zasad opartych na strategii caseworku, która stawała się procedurą źródłową dla wszystkich podstawowych sposobów oddziaływania interwencyjno-pomocowego i resocjalizacyjnego $\mathrm{w}$ pracy z podopiecznymi w naturalnym środowisku społecznym. Od pierwszego kontaktu z podopiecznymi pracownicy służb społecznych zostali zobowiązani do przestrzegania podstawowych zasad caseworku: akceptacji, komunikacji, indywidualizacji, uczestnictwa, zaufania i poszanowania prywatności oraz samoświadomości (Lalak 1995, s. 223; Beckett 2010, s. 82).

Od tego czasu znacznie poszerzona została lista reguł, do których przestrzegania zobowiązani są kuratorzy sądowi i pracownicy służb probacyjnych identyfikujący się z metodą caseworku. W pracach Andrzeja Bałandynowicza (1996), Mariana Kalinowskiego (1990), Zofii Ostrichanskiej i Anety Greczuszkin (2000), Katarzyny Sawickiej (1985; 2001), Krystyny Gromek (2001) można odnaleźć następujące zasady pracy z przypadkiem: 1) akceptacja i szacunek, 2) respektowanie, 3) samostanowienie, 4) współuczestnictwo, 5) optymizm, 6) kompleksowe traktowanie, 7) systematyczność, 8) praworządność, 9) humanizm, 10) szybkość, 11) oddziaływanie twarzą w twarz, 12) konsensus, 13) współpraca ze środowiskiem.

Wśród wymienianych przez wskazanych autorów reguł określających sens strategii caseworku powtarzają się zasady: indywidualizacji, akceptowania i szanowania oraz respektowania osoby poddanej kurateli. Podejmowane przez kuratorów sądowych i pracowników służb społecznych bezpośrednie oddziaływania metodyczne $\mathrm{w}$ warunkach probacji muszą być także zgodne $\mathrm{z}$ wartościami wynikającymi z przestrzegania zasady humanizmu i humanitaryzmu. Zgodnie z tymi regułami oddziaływania opiekuńcze, wychowawcze i resocjalizacyjne należy budować na bezwarunkowym przekonaniu, że każdy człowiek jest wartością samą w sobie i posiada prawo do samostanowienia i odpowiedzialności za własny rozwój i troskę o dobro wspólne. Pracownik służb probacyjnych, kurator sądowy musi być przekonany o tym, że każdy człowiek, niezależnie od tego, co zrobił w przeszłości, nosi w sobie godność i dobro, które przy odpowiednio ukierunkowanej pomocy i wsparciu można odkryć, odbudować, wzmocnić i rozwinąć w osobowy wymiar człowieczeństwa.

Kurator $\mathrm{w}$ pracy $\mathrm{z}$ osobą dozorowaną musi odnaleźć równowagę między postawą charakterystyczną dla bycia „stróżem prawa” i wychowawcą wspierającym podopiecznego w uporaniu się z zaistniałą sytuacją kryzysową. Gdy w pracy $\mathrm{z}$ osobą dozorowaną zaczynają dominować funkcje kontrolno-represyjne i odwetowe, wówczas skazany spostrzega zastosowany środek probacyjny jako kolejną formę kary, a to redukuje wartość wychowawczą dozoru. Dozór kuratora, jako środek probacyjny, powinien służyć promocji resocjalizacji i reintegracji społecznej skazanych w środowisku otwartym. 
Kurator respektujący w pracy z podopiecznymi zasady caseworku może skutecznie rozwiązać dostrzegalne konflikty między wymogami kontroli społecznej a oddziaływaniami polegającymi na wychowaniu, może zrównoważyć prawo do podmiotowości i autonomii osoby dozorowanej z nadaną mu przez sąd władzą i autorytetem formalnym, może wreszcie połączyć opiekuńczą kontrolę wynikającą $\mathrm{z}$ orzeczonego środka probacyjnego $\mathrm{z}$ oddziaływaniami resocjalizacyjnymi stymulującymi konstruktywne funkcjonowanie podopiecznego w środowisku społecznym (Bałandynowicz 1996, 2006, 2009; Wójcik 1999-2000; Ambrozik 2009).

Według Bałandynowicza podporządkowanie bezpośrednich oddziaływań metodycznych kuratorów sądowych zasadom opartym na strategii caseworku stanowi podstawę rozwoju klinicznego, wychowującego modelu postępowania ze skazanymi w środowisku otwartym (2011, s. 41). Bezpośrednie oddziaływania wychowawcze dostosowane do zasad caseworku stwarzają solidne podstawy do wyzwalania u podopiecznego motywacji do pracy nad sobą i naprawienia krzywd moralnych oraz materialnych spowodowanych aktem kryminalnym. Dopiero w tej perspektywie kurator sądowy może odnaleźć się w roli wychowawcy, ale też mediatora między sądem, sprawcą, ofiarą przestępstwa i społecznością lokalną (Skidmore, Thackeray 1998, s. 75; Pytka 2008, s. 75; Utrat-Milecki 2010, s. 47).

Kurator sądowy, jako przedstawiciel szczególnej służby społecznej, identyfikujący się z takimi wartościami, jak: „bratnia miłość i odpowiedzialność za los drugiego człowieka”, powinien być szczególnie wyczulony na wszelkie przejawy słabości i krzywdy społecznej, a także aspirować do roli „patrona i spolegliwego opiekuna” w pracy z podopiecznym. W ten sposób celem pracy kuratora sądowego staje się wspomaganie procesu społecznej reintegracji osoby skazanej, dążenie do rozwiązania powstałego w wyniku aktu kryminalnego konfliktu społecznego, motywowanie sprawcy do naprawienia szkody i odnowienia zerwanych więzi kulturowych, społecznych czy emocjonalnych. Tak określone zadania definiują sens pracy kuratora w wymiarze oddziaływań pedagogicznych, wychowawczych, naprawczych i odsuwają na margines funkcjonowanie tych służb w optyce urzędniczego, usługowego aparatu sądowego (Porowski 2007, s. 70).

Obowiązujące uregulowania prawne, usytuowanie służb kuratorskich na terenie sądu i brak samodzielności w zakresie postępowania wykonawczego powodują, że w odczuciu osób dozorowanych kurator jest przede wszystkim reprezentantem wymiaru sprawiedliwości, a to w istotny sposób utrudnia nawiązanie równoważnych, podmiotowych relacji z podopiecznym, rodzi brak zaufania, poczucie zagrożenia i niepewności, a także znacznie ogranicza funkcjonowanie kuratora w roli pedagoga i wychowawcy.

Pomimo oczywistych zalet kurateli wychowującej, która jest bardziej skuteczna i dostosowana do profilu osobowego skazanych w porównaniu $\mathrm{z}$ modelem 
kontrolno-represyjnym, kuratorzy nadal bardziej utożsamiają się z rolą urzędnika sądowego, a nie podmiotu wychowującego i spolegliwego opiekuna w patronackich relacjach z podopiecznym (Bałandynowicz 2006; Porowski 2007; Ambrozik 2009; Kępka 2007; Jadach 2011).

Według Bałandynowicza w klinicznym, wychowującym modelu postępowania ze skazanymi w środowisku otwartym wszelkie podejmowane oddziaływania należy podporządkować zasadom wynikającym z postępowania opartego na strategii caseworku. Jednak, aby kuratorzy mogli postępować zgodnie $\mathrm{z}$ opisanymi regułami, muszą mieć zagwarantowane „prawo do permanentnego kształtowania treści orzeczenia (jego ciągłej modyfikacji) oraz do kontroli rozumianej jako sprawdzenie efektów podjętych uprzednio działań” (2011, s. 41).

Ukształtowany w Polsce system kurateli sądowej różni się zasadniczo od innych systemów europejskich tym, że jest ściśle związany z sądownictwem. W żadnym z systemów europejskich kuratorzy nie są nadzorowani przez sędziów. Ponadto $\mathrm{w}$ naszych rozwiązaniach organizacyjnych połączono kuratelę rodzinną z kuratelą dla dorosłych.

W 1992 roku Ministerstwo Sprawiedliwości podjęło prace nad reformą służb kuratorskich w Polsce. Ustawodawca zapatrzony w dotychczasowy status kuratora pełniącego rolę "asystenta sędziego” oraz wypracowane rozwiązania organizacyjne przede wszystkim zadbał o skuteczność realizacji przez kuratorów potrzeb resortowych, nadal marginalizując funkcjonowanie kuratora jako pedagogicznego, wychowawczego pracownika sądu.

Gdy 1 maja 2004 roku Polska wstąpiła do Unii Europejskiej jasne stało się, że nasze rozwiązania ustrojowe $\mathrm{w}$ zakresie funkcjonowania sądowych służb kuratorskich muszą ulec zmianie i „aktualizacji”. Uwzględniając wypracowane przez Komitet Ministrów Rady Europy zalecenia zawarte w Europejskich Regułach dotyczących sankcji i środków alternatywnych z 1992 roku oraz standardy wypracowane w ramach międzynarodowej organizacji Stałych Konferencji Europejskich d.s. Probacji (Conférence Permanente Européenne de la Probation - C.E.P.), w pierwszej kolejności należało wprowadzić przejrzyste kryteria i procedury naboru kadry kuratorskiej, jej przygotowania i doskonalenia zawodowego (zalecenie RE-39). Następnie należało zagwarantować stosowną liczebność odpowiednio przygotowanego personelu zawodowego (zalecenie RE-38), wypracować jasne zasady i procedury postępowania dla kuratorów odpowiedzialnych za wykonywanie sankcji i środków probacyjnych (zalecenie RE-Preambuła c, 24, 73, 77), zagwarantować odpowiednie warunki pracy kuratorom zawodowym, aby mogli efektywnie realizować statutowe zadania w środowisku otwartym i przyczyniać się do zmniejszenia liczby odbywanych kar pozbawienia wolności. 
We wrześniu 2008 roku urzędnicy ministerialni, biorąc pod uwagę zalecenia zawarte w dokumentach Rady Europy, przedstawili listę rozbieżności, które należało uwzględnić w projektowanych zmianach ustawy o kuratorach sądowych. Wśród wyróżnionych kategorii zwrócono uwagę na: a) niezgodność funkcjonującego w Polsce modelu społeczno-zawodego probacji z rozwiązaniami wdrażanymi w Unii Europejskiej (por. reguła 49); b) lawinowy wzrost liczby osób oddawanych pod dozór; c) niską efektywność środków probacyjnych w zakresie zapobiegania przestępczości i zaspokajania podstawowych potrzeb egzystencjalnych osób dozorowanych (por. reguła. 90); d) niespójny, niedookreślony, chaotyczny system kontroli i oceny kuratorów sądowych; e) niską jakość pracy nadzorczej nad przebiegiem i uwarunkowaniami wykonywania środków probacyjnych (por. 41 reguła); f) niskie standardy oczekiwań etycznych od kandydatów do zawodu sądowego kuratora; g) zaniżone uprawnienia i kompetencje oraz niski status i prestiż w zawodzie kierowników zespołów i kuratorów okręgowych. Na podstawie przeprowadzonej diagnozy funkcjonującego systemu kurateli sądowej w resorcie sprawiedliwości wypracowano szereg znaczących zmian. Poniżej przytoczone zostaną rozwiązania, które w przyszłości mogą mieć istotny wpływ na metodykę pracy wychowawczej kuratorów sądowych. W pierwszej kolejności podjęto próbę modyfikacji hierarchii zadań kuratorów sądowych. Zgodnie z przyjętymi rozwiązaniami kuratorzy zostali zobowiązani do wykonywania zadań o charakterze: kontrolnym, wychowawczym, resocjalizacyjnym, diagnostycznym i profilaktycznym. W ten sposób zmieniono dotychczasowe zapisy zawarte art. 1 u.k.s., art. 65 u.p.n., art. 171 i 173 k.k.w., które w sposób jednoznaczny podkreślały zadania o charakterze wychowawczym, resocjalizacyjnym i readaptacyjnym kuratorów oraz uwzględniały kolejność funkcji określoną w art. $147 \$ 2$ u.s.p. oraz standardach światowych i europejskich (Wskazania Rijadzkie, Reguły Beijińskie, Zalecenia Rady Europy (92) 16 - preambuła pkt. a oraz Reg. 55).

Zaproponowana nowa hierarchia zadań przekreślała dotychczasowe oczekiwania tych pracowników naukowych, którzy promowali wychowujący model kurateli sądowej jako najbardziej pożądany w pracy z podopiecznymi w środowisku otwartym (Gromek 2002, s. 48). Wyeksponowanie zadań kontrolnych nie było przypadkowe. Urzędnicy resortowi, obserwując dotychczasową praktykę wykonania środków probacyjnych, dostrzegli znaczną rozbieżność między zapisanymi w ustawie funkcjami a metodyką pracy kuratorów sądowych, którzy zwłaszcza w pracy z osobami dozorowanymi wyraźnie preferowali zadania o charakterze kontrolno-represyjnym (Szymanowski 2003, s. 9; Zagórski 2008, s. 9 i n.).

Zalecane w pracy służb probacyjnych na świecie metody wywodzące się ze strategii caseworku czy networku zostały przez urzędników resortowych zmarginalizowane na rzecz wyeksponowanych zadań o charakterze kontrolno-represyjnym. 
Po zapoznaniu się z propozycjami zmian $\mathrm{w}$ ustawie o kuratorach sądowych można mieć wątpliwości, czy resortowe rozwiązania przyczynią się do naprawienia niespójnych, niedookreślonych, chaotycznych zapisów prawnych regulujących metodykę pracy kuratorów. Zaproponowane zmiany $\mathrm{z}$ wyraźnym zaakcentowaniem zadań administracyjno-kontrolnych wskazują, że w najbliższej przyszłości wykonywane środki probacyjne $\mathrm{z}$ ich udziałem mogą stać się jeszcze bardzie retrybutywne i represyjne, upodabniając się w zakresie realizowanych funkcji do kary pozbawienia wolności.

Wydaje się, że autorzy proponowanych zmian wyraźnie zapomnieli o tym, że powstanie instytucji nadzorów (dozorów) kuratorskich nad sprawcami czynów karalnych było najbardziej rewolucyjnym rozwiązaniem w prawie karnym, gdyż zostało pomyślane jako alternatywny środek sądowy dla kary pozbawienia wolności. To właśnie instytucja probacji, na pewnym etapie cywilizacyjnego rozwoju polityki karnej, wypełniła humanitarną, wychowawczą treścią nowy model sprawiedliwości. Pod koniec XIX wieku po raz pierwszy doszło do tak wyraźnego spotkania prawa i pedagogiki w procesie wykonywania środków probacyjnych. Wzmocnione i utrwalone zostało dążenie do uchronienia sprawców czynów niezgodnych z prawem od ekskluzji społecznej na rzecz reintegracji, wychowania i psychokorekcji. W postępowaniu karnym zapoczątkowany został proces, w którym zaburzona została równowaga między dążeniem do ukarania sprawcy a jego reintegracją społeczną. Pełne wdrożenie zaproponowanych zmian może spowodować, że kuratorzy sądowi identyfikujący się z wychowującym modelem probacji zostaną postawieni pod ścianą - albo pożegnają się z humanitarnymi mrzonkami na temat możliwości wychowania podopiecznych, albo ich praca zostanie oceniona jako nieefektywna i nieadekwatna do oczekiwań resortowych.

Rozsądek podpowiada, że postawieni przed takim wyborem kuratorzy poprzestaną na pełnieniu roli „asystenta sędziego” i będą posłusznie wypełniać nałożone przez ministra sprawiedliwości, prezesów sądu, kuratorów okręgowych, sędziów i kierowników zespołu zlecone zadania i czynności. A może należy mieć nadzieję, że zaproponowane przez urzędników resortowych rozwiązania przegrają w starciu z pedagogicznym powołaniem i sumieniem kuratorów i nie przekreślą tlącego się w ich sercach, pielęgnowanego od dziesięcioleci marzenia o rozwoju kurateli wychowującej, zgodnej z zasadami wielowymiarowej resocjalizacji podopiecznych z udziałem społeczeństwa.

W niedawno wydanym rozporządzeniu w sprawie sposobu wykonywania obowiązków i uprawnień przez kuratorów sądowych (rozporządzenie MS 2013, poz. 335) urzędnicy resortowi już oficjalnie zaczynają promować „inwigilacyjny”, a nie wychowawczy styl pracy kuratorów. W opublikowanym akcie prawnym następuje przesunięcie priorytetów w zakresie podstawowych funkcji kuratorów sądowych. 
W metodyce wykonywanego dozoru wyraźnie zaakcentowane zostały zadania kontrolne, dyscyplinujące i represyjne kuratorów.

Treść rozporządzenia wyraźnie wpisuje się w nową strategię pracy służb pomocowych i probacyjnych, opartą na procedurze zarządzania przypadkiem (case management), w której rola oficera probacji, pracownika służb społecznych, kuratora sądowego zostaje ograniczona do pełnienia funkcji administratora świadczonych usług oraz do wykonywania czynności kontrolno-prewencyjnch polegających na monitorowaniu zgodności zachowania osób dozorowanych z zaleceniami sądu i zapobieganiu przyszłym zachowaniom kryminalnym skazanych (Ward, Scott, Lacey 2002; Davis, Bahr, Ward 2012).

Zadania kuratora sądowego, aspirującego w modelu klinicznym opartym na strategii caseworku do roli osoby znaczącej wychowawczo, wspierającej rozwój i reintegrację społeczną podopiecznego, zostają sprowadzone do zakwalifikowania skazanego do odpowiedniej grupy ryzyka wystąpienia recydywy. W nowej strategii funkcjonowania kurateli w sposób znaczący zmieniają się relacje między kuratorem a osobą dozorowaną, gdyż już na samym początku świadczonych usług kurator zostaje zobowiązany przez sąd do udzielenia odpowiedzi na pytanie, czy pozostający pod jego dozorem skazany jest „raczej zły”, „bardzo zły”, a może należy go zaliczyć do grupy niereformowalnych kryminalistów, a to z pewnością nie ułatwia kuratorowi nawiązania bliskich, opartych na współpracy i współdziałaniu interakcji z podopiecznym (Ostrihanska 2008).

Jak pisał Jarosław Utrat-Milecki, oparta na procedurze zarządzania ryzykiem probacja

przestaje być elementem konstrukcyjnym kary kryminalnej pozbawienia wolności, ograniczającym jej negatywne skutki i ułatwiającym realizację pojednania skazanego ze społeczeństwem. Sama staje się samoistną formą organizacyjną instytucji kary kryminalnej [...] Celem bezpośrednim probacji nie jest już bowiem reintegracja społeczna, terapia czy wychowanie, ale odpowiednie zarządzanie powierzoną i sklasyfikowaną, zależnie od poziomu ryzyka, populacją skazanych, aby subiektywnie i obiektywnie zmniejszyć zagrożenie przestępczością (2006, s. 156).

W ten sposób oddziaływania probacyjne kuratora zostają ograniczone do podejmowania rozlicznych czynności prewencyjnych, które mogą doskonale sprawdzić się $\mathrm{np}$. w czasie wykonywania kary w postaci elektronicznego dozoru, ale nie wyczerpują wszystkich funkcji zawartych w ustawie o kuratorach sądowych. Rola kuratora zostaje zredukowana do informowania sądu o tym, która z osób dozorowanych może $\mathrm{z}$ dużym prawdopodobieństwem popełnić $\mathrm{w}$ najbliższej przyszłości kolejny akt kryminalny. 
Kurator przestaje być oceniany za jakość wywieranego wpływu wychowawczego $\mathrm{w}$ interakcjach $\mathrm{z}$ podopiecznym, ponieważ jego skuteczność jest mierzona poziomem kontroli sprawców w sposób szczególny zagrożonych ryzykiem recydywy. Co więcej, samo wykluczenie osoby dozorowanej ze społeczeństwa i ponowne skierowanie do instytucji penitencjarnej nie będzie już odbierane jako porażka wychowawcza kuratora, gdyż będzie on przede wszystkim rozliczany za skuteczne podejmowanie i wykonywanie czynności kontrolnych. W świetle nowych rozwiązań metodycznych wykonywane $\mathrm{z}$ udziałem kuratora środki probacyjne przestają być alternatywą dla kary kryminalnej. Dozór w warunkach probacji zaczynie różnić się od kary pozbawienia wolności jedynie intensywnością kontroli skazanych oraz mniejszymi kosztami (Utrat-Milecki 2006). Kurator, zamiast spełniać się w roli wychowy i spolegliwego opiekuna, staje się urzędnikiem sądowym odpowiedzialnym za ekskluzję społeczną osób dozorowanych w imię zapewnienia bezpieczeństwa i ładu prawnego. W ten sposób będzie mógł już oficjalnie odrzucić maskę wychowawcy i przystąpić do pełnienia roli „stróża prawa” i „sądowego policjanta" (Węgliński 2010).

Najbardziej obawiam się tego, że zaproponowane rozwiązania organizacyjno-metodyczne bardzo spodobają się wielu rodzimym kuratorom sądowym. Ponieważ $\mathrm{w}$ dokumentach programowych $\mathrm{z}$ ostatniego kongresu kuratorów można odnaleźć duże przyzwolenie uczestników dla praktycznej realizacji podstawowej tezy twórców i protagonistów proponowanych zmian, według których nie po to karzemy sprawców, aby ich wychowywać czy resocjalizować, ale po to, żeby ograniczyć ryzyko związane ze zjawiskiem przestępczości (Ward, Scott, Lacey 2002; Wójcik 2012). Wskazana zasada już wcześniej zyskała uznanie wielu populistycznych polityków $\mathrm{w}$ różnych krajach (w tym także w Polsce), według których spotkanie pedagogiki i prawa oraz wiara $\mathrm{w}$ wychowanie sprawców przestępstw może się zrodzić tylko w umyśle „humanitarnych idiotów”. Również w odczuciach tzw. opinii publicznej, zastraszanej katastroficznymi doniesieniami prasowymi na temat drastycznych aktów kryminalnych, ciągle można odnaleźć powszechny aplauz dla retrybutywnych, odwetowych, represyjnych postaw wobec przestępców (Cieślik, Sijka 2004; Węgliński 2010).

Efektywność programowanych oddziaływań korekcyjnych będzie uzależniona od specyficznych cech wynikających z przebiegu procesu dezadaptacji społecznej obiektu oddziaływań oraz od zasobów i czynników ryzyka środowiska, w którym aktualnie funkcjonuje dana osoba (Andrews, Bonta 2010, s. 506). Granice skutecznej resocjalizacji osób dozorowanych wyznacza układ tzw. statycznych czynników ryzyka (static risk faktors), czyli empirycznych predyktorów przyszłych zachowań przestępczych. Do tych czynników zalicza się takie cechy, jak: rodzaj popełnionego przestępstwa, długość wyroku, nadużywanie narkotyków i alkoholu, wiek 
czy uprzednie leczenie psychiatryczne. Wyodrębnienie i oszacowanie nasilenia tych czynników będzie decydować o szansach skutecznej resocjalizacji. Również styl oddziaływania korekcyjnego i oferowana pomoc będą uzależnione od (oprócz wymienionych czynników ryzyka) zdiagnozowania takich cech osoby dozorowanej, jak: status etniczny i kulturowy, poziom kompetencji interpersonalnych i poznawczych, poziom środowiskowego wsparcia, motywacji do współdziałania oraz specyficznych, sytuacyjnych aspektów związanych z przyszłą, możliwą aktywnością przestępczą. Prawo do intensywnej pomocy przysługuje tym skazanym, u których zdiagnozowano kryminogenne potrzeby (Andrews, Bonta 2010, s. 46; Sztuka 2013, s. 235).

W modelu zarządzania ryzykiem podstawowym kryterium oceny skuteczności oddziaływań korekcyjnych jest wskaźnik recydywy przestępczej (tzw. poprawa jurydyczna), który nie uwzględnia podstawowych zmian w zakresie dojrzewania społecznego, rozwoju moralnego, osobowego czy duchowego obiektu oddziaływań resocjalizacyjnych oraz jego zasobów samorealizacyjnych i samowychowawczych (Sztuka 2013, s. 249; Machel 2003, s. 21).

Przeciwnicy rozwiązań metodycznych opartych na zarządzaniu ryzykiem zwracają uwagę na fatalistyczną rolę statystycznych procedur rozpoznawania, szacowania statycznych czynników ryzyka oraz ich decydującą rolę w prognozowaniu popełnienia w przyszłości aktów kryminalnych. Zdiagnozowanie wysokiego prawdopodobieństwa wystąpienia recydywy może prowadzić do zaniechania kontynuowania oddziaływań korekcyjnych w warunkach wolności dozorowanej i umożliwienie wymiarowi sprawiedliwości zastosowania instrumentu ekskluzji, opartego na wykluczeniu skazanego z funkcjonowania w środowisku otwartym i przeniesienia do instytucji o charakterze izolacyjno-więziennym. Według Mariusza Sztuki zaniechanie oddziaływań korekcyjnych eliminujących czynniki ryzyka i orzekanie kolejnych sankcji karnych na podstawie oszacowania prawdopodobieństwa popełnienia przestępstwa w przyszłości jest sprzeczne z zasadą proporcjonalności kary. Ponadto powiązanie strategii zarządzania ryzykiem z praktyką orzeczniczą o charakterze segregacyjnym staje się środkiem ekskluzji społecznej sprawców i jest sprzeczne z istotą probacji, której celem jest skuteczna readaptacja osoby dozorowanej w środowisku otwartym. Bezkrytyczne wdrażanie zaproponowanych rozwiązań grozi powstaniem gułagów w XXI wieku (2013, s. 248 i n.).

Pomimo tych formalnych przeszkód wynikających z proponowanych rozwiązań organizacyjno-metodycznych należy stale uświadamiać kuratorom, że w modelu wychowującym wykonywania środków probacyjnych centralne miejsce zajmuje respektowanie zasad opartych na strategii caseworku i promowanie resocjalizacji z udziałem osób i instytucji znaczących w obrębie społeczności lokalnej. Tylko w ten sposób można skutecznie rozwiązywać problemy readaptacyjne osób 
dozorowanych, nawiązywać z nimi relacje oparte na niezawodnym świadectwie wsparcia oraz stymulować i utrwalać pozytywny klimat społeczny sprzyjający wychowaniu skazanych w warunkach wolności dozorowanej.

$\mathrm{W}$ toku dojrzewania zawodowego kurator sądowy musi umieć dostrzegać powstające $\mathrm{w}$ jego działalności sprzeczności wynikające $\mathrm{z}$ obecnego stanu prawnego i usytuowania w resorcie sprawiedliwości. Następnie powinien dokonać dojrzałego i świadomego wyboru wartości oraz celów, które przybliżą go do ogólnoświatowych standardów pracy społecznej. Skuteczność resocjalizacji w warunkach wolności dozorowanej w sposób oczywisty uzależniona jest od predyspozycji i cech kuratora sądowego, jego zaangażowania, troski o podopiecznego, świadomości motywu służebności wobec innych, wreszcie autopercepcji wychowawczej i wewnętrznej zgodności preferowanych sposobów wywierania wpływu wychowawczego z humanistycznymi i humanitarnymi wartościami służb społecznych.

W zaprojektowanych badaniach postanowiono sprawdzić, jak bezpośrednie oddziaływania wychowawcze kuratorów dla dorosłych wpisują się w kliniczno-wychowawczy model probacji.

\section{ZAMIERZENIA BADAWCZE}

Ogólnie nasza wiedza na temat bezpośrednich oddziaływań metodycznych społecznych kuratorów dla dorosłych w zakresie wykonywanych środków probacyjnych jest bardzo ograniczona. Nie przeprowadzono odpowiednio przygotowanych badań poświęconych metodyce oddziaływań wychowawczych społecznych kuratorów sądowych $\mathrm{w}$ pracy z dozorowanymi. Nadal niewiele możemy powiedzieć na temat przygotowania metodycznego, kompetencji, umiejętności wychowawczych kuratorów niezbędnych w pracy z podopiecznymi o zróżnicowanym stopniu wykolejenia przestępczego.

Wszelka działalność, która ma prowadzić do osiągnięcia określonego celu, wymaga odpowiedniego postępowania. W pracy zastosowano przekrojowy plan badań empirycznych utożsamiany z modelem sondażowym (Nachmias, Frankfort-Nachmias 2001, s. 113). W procedurze sondażu diagnostycznego możliwy do zastosowania dobór technik badawczych służy do gromadzenia informacji o atrybutach strukturalnych i funkcjonalnych badanych zjawisk społecznych, opisywanych na podstawie opinii i poglądów specjalnie dobranych grup respondentów (Pilch 2001, s. 80).

Zasadniczym celem podjętych badań będzie analiza bezpośrednich oddziaływań metodycznych społecznych kuratorów sądowych $\mathrm{w}$ pracy $\mathrm{z}$ osobą dozorowaną w naturalnym środowisku społecznym. W zaprojektowanych badaniach 
empirycznych zamierzano uzyskać odpowiedzi na następujące pytanie: „Jaka jest autopercepcja bezpośrednich oddziaływań wychowawczych społecznych kuratorów sądowych $\mathrm{w}$ pracy $\mathrm{z}$ dozorowanymi zróżnicowanych pod względem cech asocjalności?”.

Do oceny jakości oddziaływań wychowawczych zastosowano specjalnie skonstruowany kwestionariusz, który składał się z pytań ukierunkowanych na poznanie podstawowych aspektów metodycznych pracy kuratorów sądowych, a zwłaszcza preferowanych zasad, metod i form oraz środków wywierania wpływu wychowawczego. Badani kuratorzy sądowi, odpowiadając na pytania, mogli dokonać szczegółowej retrospekcji przebiegu i zakresu stosowanych sposobów bezpośrednich oddziaływań wychowawczych.

$\mathrm{W}$ przygotowanym doniesieniu badawczym zostanie zaprezentowany materiał empiryczny zgromadzony na podstawie specjalnie skonstruowanej listy pytań w postaci trzonów zdań niedokończonych. Uzupełniając początki zdań, kuratorzy mogli w sposób swobodny zaprezentować opinie i uczucia związane z osobą dozorowaną, celem, sensem i efektywnością resocjalizacji w warunkach wolności dozorowanej.

Badaniami objęto 50 społecznych kuratorów sądowych. W grupie dominują kobiety (66\%). Tylko co trzeci z kuratorów był mężczyzną (34\%). Wśród badanych przeważają osoby w wieku powyżej 30. roku życia (92\%). Tylko 4 kuratorów nie miało ukończonych 30 lat, a 40\% badanych ukończyło 40 lat. Ponadto okazało się, że w grupie dominują osoby żyjące w związku małżeńskim (84\%). Większość społecznych kuratorów legitymowało się średnim wykształceniem (52\%). Wyższe studia magisterskie realizowane głównie w trybie niestacjonarnym ukończyło $40 \%$ badanych. W grupie kuratorów z wykształceniem wyższym dominują osoby, które ukończyły studia o profilu pedagogicznym $(37,5 \%)$ lub prawniczym $(29,2 \%)$. Badani kuratorzy dla dorosłych legitymują się zróżnicowanym stażem pracy zawodowej i pedagogicznej. Ponad dziesięcioletni ogólny staż pracy zawodowej odnotowano u 76\% respondentów. W roli kuratora sądowego ponad połowa badanych osób pracuje dłużej niż 6 lat (52\%). Jednak powyżej 15 lat wykonuje powierzoną funkcję tylko 12\% uczestniczących w badaniach kuratorów. Przeciętny ogólny staż pracy w grupie wynosił 17,3 lat. Z zebranych informacji wynika, że społeczni kuratorzy z reguły prowadzili 10 dozorów własnych (74\%). Opisywany sondaż był realizowany przez studentów seminariów prowadzonych pod moim kierunkiem. 


\section{ANALIZA I INTERPRETACJA WYNIKÓW BADAŃ}

Wszelkie oddziaływania wychowawcze i pomocowe należy opierać na bezpośrednich, bliskich relacjach z podopiecznym. Tylko bezpośredni kontakt kuratora z osobą dozorowaną stwarza szansę na przełamanie zależności formalnej, urzędniczej i zawiązanie relacji opartych na zależności wewnętrznej, która motywuje skazanego do współdziałania w realizowaniu zadań wynikających z oczekiwań sądu.

Poszukując odpowiedzi na pytanie, czy i w jakim stopniu kuratorzy sądowi utożsamiają się z wychowującym modelem oddziaływań probacyjnych, zaproponowano badanym ustosunkowanie się do treści pytań opracowanych w postaci trzonów, czyli początków zdań, które należało uzupełnić. Pierwsze z tak skonstruowanych pytań polegało na dokończeniu zdania: „Wychowanie oznacza...”.

Chociaż w badanej grupie kuratorów społecznych co trzecia osoba legitymowała się wyższym wykształceniem pedagogicznym, to przy definiowaniu terminu „wychowanie” dominowało podejście tradycyjne, sprowadzające wywierany wpływ na podopiecznych do „kształtowania osobowości” (52\%). Ponadto co piąty kurator w myśleniu o wychowaniu brał pod uwagę „wskazywanie właściwej drogi postępowania” oraz „oddziaływanie przykładem własnym” (18\%).

W świadomości badanych osoby dozorowane są przedmiotem podejmowanych oddziaływań, a sam proces wywierania wpływu jest postrzegany w sposób jednostronny: kurator wchodzi w rolę nadawcy, a podopieczny staje biernym odbiorcą adresowanych oddziaływań. Takie ukierunkowanie wychowania musi budzić zrozumiały niepokój, gdyż w ten sposób ogranicza się autonomię i wolność wychowanka w programowanych sytuacjach wychowawczych, a to z kolei może wyzwalać po stronie podopiecznego bierność i postawę lękową lub skłaniać do otwartego buntu, a nawet agresji (Śliwerski 2001).

Tymczasem jednym z podstawowych kryteriów efektywności oddziaływań wychowawczych jest wdrażanie podopiecznego do realnego współuczestniczenia w procesie kształtowania własnej osobowości (Łobocki 1983; Łukaszewski 1983; Śliwerski 2010). W tym ujęciu wychowanie polega na podtrzymywaniu relacji dwustronnych między wychowawcą i wychowankiem, w wyniku których dochodzi do zwrotnego oddziaływania równoważnych podmiotów wychowania, dzięki czemu każdy z nich może się rozwijać i zmieniać (Filek 1984). Takie wzajemne oddziaływanie jednej osoby na drugą będzie możliwe tylko, gdy podopieczny w sposób dobrowolny otworzy się na zamierzone oddziaływania wychowawcze, czyli pojawi się to, co psychologowie określają mianem „wychowalności”, „chęci do współdziałania z kuratorem-wychowawcą” (Han-Ilgiewicz 1995; Śliwerski 2010).

W warunkach wolności dozorowanej wychowanie podopiecznych może polegać na wzajemnym odkrywaniu zasobów dobra, które przy stworzeniu odpowiednich 
warunków środowiskowych i profesjonalnym wsparciu ze strony kuratora sądowego i osób znaczących rozwiną się w akceptowane społecznie formy aktywności autoresocjalizacyjnej i samowychowawczej motywującej osobę dozorowaną do osiągnięcia satysfakcjonującej jakości życia osobistego w zgodzie z regułą dobra wspólnego (Węgliński 2015).

Instytucję kurateli sądowej można rozpatrywać jako system społeczny powołany do wykonywania określonych funkcji, zadań i czynności z zakresu polityki kryminalnej. Analizując pracę społecznych kuratorów dla dorosłych, należy pamiętać, że z reguły wykonują oni dwie podstawowe czynności: przeprowadzają dozory osobiste i wywiady środowiskowe (Jedynak i Stasiak 2008, s. 159).

$\mathrm{Na}$ tym tle interesująca będzie próba oceny opinii badanych, którzy zostali poproszeni o dokończenie zdania: „Najważniejszym zadaniem resocjalizacji jest...”. Opinie kuratorów na temat najważniejszych zadań resocjalizacyjnych podejmowanych w toku wykonywanego dozoru były następujące. Dla większości najważniejsze zadanie $\mathrm{w}$ resocjalizacji $\mathrm{w}$ środowisku otwartym sprowadza się do „powstrzymanie podopiecznych od zachowań przestępczych” (42\%). Według Henryka Machela jest to jeden $\mathrm{z}$ minimalnych celów możliwych do osiągnięcia $\mathrm{w}$ pracy $\mathrm{z}$ osobami skazanymi (2003, s. 22).

Pogłębione, psychopedagogiczne spojrzenie na oddziaływania resocjalizacyjne $\mathrm{w}$ środowisku otwartym prezentuje co trzeci z badanych, pisząc, że istotnym zadaniem będzie dokonanie „zmiany w postawach osób dozorowanych” (32\%). Spowodowanie poważnych przeobrażeń w osobowości i zachowaniu podopiecznych to coraz częściej podnoszone kryterium świadczące o skuteczności wszelkich oddziaływań resocjalizacyjnych (Bartkowicz 2013, s. 20).

Niestety w resorcie sprawiedliwości oraz w Krajowym Stowarzyszeniu Zawodowych Kuratorów Sądowych przy ocenie skutecznej pracy kuratorów akcentuje się głównie liczbę wykonanych czynności, np. złożonych przez kuratora wizyt u podopiecznego, dyżurów na terenie sądu, udokumentowanych w karcie czynności rozmów z podopiecznym, liczbę przeprowadzonych wywiadów itp. (Jedynak, Rzepniewski i Pawlaczyk 2004, s. 8; Jedynak 2008; Węgliński 2008).

Wydaje się, że za takim resortowym rozwiązaniem opowiada się co dziesiąty $z$ badanych kuratorów (12\%). Tymczasem ewaluacja związku, jaki zachodzi między realizowanymi przez kuratora czynnościami a zmianą w postawach i zachowaniu podopiecznych, jest standardem przy pomiarze skuteczności interwencji pracowników profesjonalnej służby społecznej (Garwin i Seabury 1998, s. 348).

Oddziaływania resocjalizacyjne prowadzone $\mathrm{w}$ warunkach probacji coraz częściej opisuje się w kategoriach inkluzji, readaptacji czy reintegracji społecznej osób dozorowanych, gdyż w pedagogice resocjalizacyjnej kary kryminalne i proces karania ujmowany jest w innym kontekście, niż ma to miejsce w penologii. Readaptacja 
społeczna może być definiowana jako proces ponownego dostosowania skazanego, dozorowanego do społeczeństwa, ale może też oznaczać dostosowanie systemu społecznego do specyficznych sytuacji i cech społeczno-demograficznych jednostek wykluczonych przez ten system (Pytka 2013).

Społeczna integracja skazanych może być wzmacniana zarówno w wymiarze strukturalno-funkcjonalnym, jak i normatywnym przez działania o charakterze inkluzji społecznej (social inclusion), czyli „tworzenie pewnych całościowych wariantów życia społecznego, przezwyciężających to, co społecznie różnicujące, czy przeciwstawne, a w następstwie segregujące" (Frysztacki 2005, s. 17). Inkluzja społeczna jest też opisywana jako stwarzanie osobom zagrożonym wykluczeniem społecznym możliwości uzyskania szans i zasobów potrzebnych do pełnego uczestnictwa w życiu społecznym i kulturalnym (Jedynak, Rzepniewski i Pawlaczyk 2004, s. 10). Zgodnie z art. 165 k.k.w. zadaniem kuratora jest udzielenie stosownej pomocy w społecznej readaptacji skazanych. Za tym rozwiązaniem opowiedziało się $14 \%$ badanych kuratorów społecznych. Integracja, wsparcie społeczne, readaptacja i resocjalizacja skazanych $\mathrm{w}$ istotny sposób uwarunkowana jest środowiskiem - inaczej kształtować się będą oddziaływania resocjalizacyjno-readaptacyjne i pomocowe w warunkach izolacji więziennej, a inaczej w warunkach probacji.

Dlatego w toku dalszych badań poproszono kuratorów społecznych o zaprezentowanie opinii na temat istoty resocjalizacji w środowisku otwartym. Kuratorzy podjęli próbę ukończenia zdania, które brzmiało: „Resocjalizacja w środowisku otwartym polega na...”.

Odpowiedzi na to pytanie pokazały, że w badanej grupie społecznych kuratorów dostrzegalna jest polaryzacja poglądów na temat wykonywania środków probacyjnych. Za częstymi kontaktami z podopiecznym i świadczeniem niezbędnej pomocy opowiedziało się $30 \%$ kuratorów, a za stałą i ścisłą kontrolą osób dozorowanych $-28 \%$. Ponadto według społecznych kuratorów sensowne oddziaływania resocjalizacyjne w środowisku otwartym mogą polegać na „wskazywaniu pozytywnych wzorów" (16\%). Gdy połączymy odpowiedzi zawierające odniesienia do udzielenia pomocy osobom dozorowanym przy podtrzymywaniu stałej współpracy z instytucjami zewnętrznymi oraz na wywieraniu wpływu przez przykład własny kuratora, okaże się, że ponad połowa badanych (56\%) opowiada się za modelem wychowawczym i strategiami pomocowymi w wykonywaniu środków probacyjnych.

Należy sądzić, że nawet ci kuratorzy, którzy zdecydowanie opowiadają się za kontrolą dozorowanych, przede wszystkim mają na uwadze przestrzeganie przez podopiecznych nałożonych w okresie próby obowiązków i zadań, co w połączeniu udzielonym wsparciem i pomocą będzie skutecznie zapobiegać powrotowi na drogę przestępstwa. Dostrzegana przez społecznych kuratorów potrzeba częstych kontaktów z podopiecznymi, poza czynnościami opiekuńczymi, sprzyjać będzie tworzeniu 
klimatu zaufania i otwartości, który jest warunkiem koniecznym do przełamania zależności formalnej i nawiązania współpracy opartej na zależności wewnętrznej (Heine 1982; Marzec-Holka 1994; Ostrihanska i Greczuszkin 2000).

Podmiotowe, partnerskie relacje kuratorów z osobami dozorowanymi sprzyjać będą uświadomieniu podopiecznym sytuacji, w jakiej się znaleźli po orzeczeniu środka probacyjnego, i asymilowaniu informacji koniecznych do rozładowania napięcia i stresu związanego z oczekiwaniami sądu i środowiska, w którym aktualnie funkcjonują. Partnerskie, dwukierunkowe relacje będą wzbudzać u podopiecznych wiarę w pokonanie zaistniałych trudności (Kopeć-Chrościcka 1984; Bałandynowicz 2002). Ogólnie zaprezentowane opinie przybliżają badanych kuratorów społecznych do modelu opiekuńczo-wychowawczego, który zawiera w sobie wiele istotnych zasad charakterystycznych dla strategii caseworku.

Poza podejmowanymi i realizowanymi czynnościami o charakterze pomocowo-readaptacyjnym najważniejszym zadaniem kuratorów sądowych jest resocjalizacja sprawcy przestępstwa w warunkach probacji. Mając to na uwadze, poproszono badanych kuratorów o wypowiedzenie się na temat oddziaływań resocjalizacyjnych możliwych do realizacji w środowisku otwartym. Kuratorzy mogli przedstawić opinie, zastanawiając się nad treścią następującego zdania: „O resocjalizacji można mówić gdy...".

Zgodnie z oczekiwaniami dla badanych najbardziej widocznym wskaźnikiem świadczącym o skutecznej resocjalizacji jest „poprawa zachowania” osób dozorowanych. Taką opinię zaprezentował prawie co drugi z kuratorów (44\%). Ponadto co trzeci uważa, że postęp w resocjalizacji będzie możliwy do osiągnięcia, gdy „osoba dozorowana współpracuje z kuratorem" (30\%). Natomiast ostatnim, najprostszym do wskazania kryterium skutecznej pracy resocjalizacyjnej, za którym opowiedziało się $26 \%$ respondentów jest „niepowracanie podopiecznych do przestępstwa” (26\%). Stosowanie powyższego kryterium odwołującego się do braku recydywy przestępczej pozostawia bez odpowiedzi pytanie, czy rezultaty pracy kuratora są efektem zmian w osobowości podopiecznego, czy też wynikiem surowości kary (Heine 1982, s. 63).

Jeżeli o braku recydywy zadecydowała jedynie obawa przed karą, można spodziewać się, że po jej wygaśnięciu dozorowany powróci na drogę przestępstwa, a wynik dozoru będzie miał charakter jedynie fasadowy. Opinie badanych kuratorów na temat „resocjalizacji” czy też „zresocjalizowania” koncentrują się wokół wskaźników behawioralnych i ograniczania możliwości wejścia na drogę przestępstwa osoby dozorowanej.

Jednak zabezpieczenie społeczeństwa przed sprawcą przestępstwa to tylko niewielka część zadań wynikających z celu resocjalizacji sprowadzonego do pojęcia udanej readaptacji społecznej, rozumianej jako dynamiczny i ciągły proces 
przystosowania rozwijającej się jednostki do zmieniających się warunków otaczającego ją środowiska (Kopaliński 1968; Lafon - za Pytka 1986, s. 71).

Resocjalizacja może być rozumiana jako odkrywanie, kształtowanie i rozwijanie osoby ludzkiej do takiego poziomu funkcjonowania, aby mogła czynnie i samodzielnie żyć w społeczeństwie bez szkody dla siebie i innych (Hurrelmann 1994, s. 41 i n.). Resocjalizacja, której celem jest rozwój biopsychospołeczny podopiecznego, ma wiele punktów wspólnych $\mathrm{z}$ wychowaniem resocjalizacyjnym, $\mathrm{w}$ węższym rozumieniu oznaczającym „nauczanie korygujące i wzbogacające nastawienia”, a w ujęciu szerszym zawiera oddziaływania polegające na "uczeniu nastawień i postaw" oraz na „opiece i psychoterapii” (Czapów 1978, s. 5 i n.).

W dalszej części badań opartych na teście zdań niedokończonych kuratorzy społeczni wypowiedzieli się na temat oceny poczucia sukcesu w pracy z podopiecznymi. Okazało się, że dla większości pedagogów resocjalizacyjnych udana adaptacja społeczna podopiecznych i brak recydywy przestępczej jest podstawową miarą ich sukcesu zawodowego (Pytka 1986; Marzec-Holki 1994). Z tym stanowiskiem zgodzili się wszyscy badani, dla których sukcesem jest to, że podopieczny zaczyna „normalnie” funkcjonować (64\%), „nie popełnia ponownych przestępstw” (18\%), a jego „poprawa zachowania” (14\%) umożliwia sformułowanie wniosku o „zniesienie dozoru" (4\%).

Jednak przed każdym pedagogiem resocjalizacyjnym można stawiać jeszcze bardziej ambitne cele, których zrealizowanie będzie świadczyć o osiągnięciu sukcesu pedagogicznego. Takim znaczącym zadaniem może być umotywowanie podopiecznych do aktywnego dążenia do „samourzeczywistnienia”, „samowychowania” i „autoresocjalizacji” (Pytka 2000, s. 19; Fidelus 2012, s. 85; Węgliński 2013, s. 343).

W bezpośrednich oddziaływaniach metodycznych opartych na zasadach caseworku, pomocniczości łatwiej będzie kuratorowi stworzyć podstawy do osobowego rozwoju podopiecznych, konstruktywnego funkcjonowania w naturalnym środowisku społecznym, ale też do naprawienia krzywd moralnych i materialnych spowodowanych dokonanym aktem kryminalnym. Dopiero w tej perspektywie kurator sądowy może cieszyć się z odniesionego sukcesu w roli wychowawcy oraz pracownika szczególnej służby społecznej (Skidmore i Thackery 1998, s. 75; Pytka 2008, s. 75; Utrat-Milecki 2010, s. 47).

Ciągle należy jednak pamiętać, że usytuowany w strukturze sądu społeczny kurator ma ograniczone możliwości działania. Pomimo profesjonalnego przygotowania metodycznego potrzebuje wsparcia ze strony różnych instytucji profilaktyczno-wychowawczych, pomocowych i resocjalizacyjnych. Kurator sądowy, tak jak każdy pedagog resocjalizacyjny, bardzo często w toku wykonywania zadań statutowych narażony jest na zawód czy frustrację wynikającą z braku sukcesu w pracy wychowawczej (Bley 1988, s. 254). 
Analizując obserwowane zmiany w postępowaniu podopiecznych, kurator sądowy cały czas musi trafnie oceniać i analizować reakcje i zachowania osób dozorowanych, zwracając szczególną uwagę na możliwość wystąpienia pozornych, fasadowych, udawanych odruchów sumienia, przez które podopieczny może jedynie dążyć do skrócenia okresu wykonywanego środka probacyjnego.

Pamiętając o możliwości wystąpienia fasadowej postawy osób dozorowanych, poproszono badanych o zaprezentowanie ogólnej opinii przez dokończenie frazy: „Podopieczny jest dla mnie...”.

W nakreślonym przez kuratorów społecznych obrazie osoby dozorowanej wyraźnie dominują dwie tendencje. Podopieczny to osoba, której należy udzielić niezbędnej „pomocy” (38\%), ale też należy ją „kontrolować” (30\%). O „partnerstwie”, które, jak to podkreślano wcześniej, jest podstawą współdziałania i współpracy z podopiecznymi, myśli co piąty z badanych. Należy też zauważyć, że o zaistniałych problemach w kontakcie $\mathrm{z}$ dozorowanymi, którzy czasami zachowują się jak „trudny uczeń” informuje co dziesiąty z kuratorów społecznych.

Na każdym etapie pracy z osobą dozorowaną kurator sądowy musi poszukiwać konsensusu, porozumienia, kompromisu między oczekiwaniami wymiaru sprawiedliwości a możliwościami i zasobami podopiecznego. W każdej fazie pracy z osobą oddaną pod dozór kurator sądowy jest odpowiedzialny za poszanowanie prawa podopiecznego do określania ważnych, istotnych dla niego celów i wartości życiowych oraz sposobów ich realizacji (Kwaśniewski 1995, s. 115; Garwin i Seabury 1998 , s. 62).

W tym miejscu należy zwrócić uwagę na to, że co drugi z podopiecznych badanych kuratorów społecznych został zakwalifikowany do grupy osób z problemem alkoholowym. W relacjach z osobą dozorowaną mającą skłonność do niekontrolowanego spożywania alkoholu kuratorzy sądowi mogą bardzo łatwo wpaść w pułapkę potępiania, zniechęcenia, a nawet zrezygnować z podejmowania próby motywowania podopiecznych do zmiany stylu życia. Tymczasem w zaprezentowanych opiniach dominuje postawa oparta na podtrzymywaniu współpracy i udzielaniu stosownego wsparcia.

Badani kuratorzy potwierdzili dążenie do konsekwentnego wykonywania stojących przed nimi zadań, a ponadto uniknęli ambiwalentnych postaw wobec podopiecznych w postaci łatwego przechodzenia od „potępienia” osoby dozorowanej z problemem alkoholowym do stwarzania jej nierealnej nadziei na łatwe rozwiązanie podstawowych problemów wynikających z uzależnienia.

W dalszej części testu zdań niedokończonych kuratorzy ponownie mogli zastanowić się nad oceną granic resocjalizacji z uwzględnieniem roli i zadań podopiecznego. Badani zmierzyli się z treścią następującego zdania: „Zresocjalizowany podopieczny to taki, który...”. 
Przy próbie oceny możliwości zresocjalizowania sprawców przestępstwa w warunkach wolności dozorowanej respondenci przede wszystkim mocno zaakcentowali konieczność zmotywowania podopiecznych do „współpracy” z kuratorem w toku wykonywania zadań określonych przez sąd (58\%).

Nie wiemy, czy badani, myśląc o nawiązaniu współpracy i współdziałania z podopiecznym, w pełni zdawali sobie sprawę $z$ tego, że zrealizowanie tego celu nie będzie możliwe bez systematycznie podtrzymywanych relacji partnerskich z osobą dozorowaną. Ponadto $\mathrm{w}$ pracy z podopiecznym $\mathrm{z}$ problemem alkoholowym kurator bardzo często doświadcza ograniczonej motywacji i chęci do współdziałania przy próbie dokonania zmiany dotychczasowych wzorów spożywania alkoholu. W zaistniałej sytuacji oporu i niechęci podopiecznego do dokonania zmiany kurator musi wykazać się wysokim poziomem zdolności empatycznych, które ułatwią mu trafne odczytania i zrozumienie doświadczanych przez osobę dozorowaną frustracji i ograniczeń. Tylko w ten sposób będzie mógł bez oceniania i etykietowania podopiecznego pogłębić wgląd w ambiwalencje i ambitendencje towarzyszące wychowankowi przy próbie zaprzestania nadużywania alkoholu. Empatyczne słuchanie, odwoływanie się do ważnych dla podopiecznego celów i wartości życiowych, identyfikowanie doświadczanych sprzeczności, stymulowanie posiadanych zdolności i zasobów określa właściwy styl pracy z osobą z problemem alkoholowym, który będzie kluczem do dokonania oczekiwanej zmiany. W zakresie terapii motywującej styl ten został przez Williama Millera określony jako „partnerstwo terapeutyczne” (2009, s. 37 i n.).

Ogólnie z dotychczas wykonanych badań wynika, że zarówno zawodowi, jak i społeczni kuratorzy sądowi dla dorosłych są przekonani, że o skutecznym wykonywaniu zadań statutowych w pierwszej kolejności decyduje zdobyte doświadczenie oraz zdolności komunikacyjne, negocjacyjne i empatyczne, a także umiejętna współpraca z osobami dozorowanymi i instytucjami profilaktyczno-prewencyjnymi, pomocowymi i resocjalizacyjnymi (Witkowska-Paleń 2008, s. 108; Wójcik 2010, s. 235; Gogacz 2012, s. 156).

W zaprezentowanych opiniach odnoszących się do przedstawienia kryteriów świadczących o zresocjalizowaniu osoby dozorowanej co piąty z badanych wskazał na doświadczany przez osobę dozorowaną „żal” z powodu popełnionego przestępstwa. Manifestowane przez podopiecznego poczucie winy, smutku, dyskomfortu z powodu wyrządzonej ofiarom krzywdy i cierpienia może być odczytywane przez społecznych kuratorów jako sygnał odradzającego się sumienia i rozwoju uczuć prospołecznych. Gdyby tak rzeczywiście było, to według Dariusza Buksika „wrażliwość sumienia można traktować jako pewną dyspozycję do reagowania na dobro i zło moralne zgodnie z przyjętą przez podmiot hierarchią wartości" (2003, s. 33). 
Doświadczany przez osobę dozorowaną żal po dokonaniu przestępstwa może, w dalszej perspektywie, motywować do zadośćuczynienia i naprawienia wyrządzonej ofiarom szkody, a to z kolei określa podstawowy sens kary kryminalnej w paradygmacie sprawiedliwości naprawczej (Węgliński 2007; Lewicka-Zelent 2013). W tym momencie należy pochwalić wszystkich kuratorów społecznych, którzy odrzucając model retrybutywny, odwetowy kary kryminalnej, poszukują socjopsychopedagogicznych, a nie formalno-prawnych uzasadnień dla podejmowanych oddziaływań wychowawczych.

Następnie badani mogli się wypowiedzieć na temat czynników, które wpływają na osiągnięcie założonych celów resocjalizacyjnych, analizując treść następującego zdania: „Aby osiągnąć założone cele oddziaływań resocjalizacyjnych należy...”. Skuteczna realizacja założonych celów w pracy z osobą dozorowaną przede wszystkim uwarunkowana jest posiadanymi kompetencjami metodycznymi kuratorów sądowych oraz predyspozycjami osobowymi. Jakość i efektywność wykonywanych zadań i czynności będzie zależała także od motywacji i zaangażowania w rozwiązywanie trudnych problemów adaptacyjnych podopiecznych. Na skuteczność oddziaływań wychowawczych kuratorów sądowych w środowisku otwartym duży wpływ wywiera także jakość komunikacji z podopiecznymi oraz z osobami wspierającymi proces resocjalizacji dozorowanych w naturalnym środowisku społecznym. Tymczasem według $38 \%$ badanych o efektywności wykonywanych czynności i zadań przede wszystkim decyduje „konsekwencja kuratora wobec podopiecznego”.

Wyrażona przez kuratorów opinia jest zbieżna z opracowanymi przez Malcolma Lacey’ego zasadami nowej filozofii probacji, a zwłaszcza z regułą mówiącą, że „dozór powinien mieć charakter dyscyplinujący, to znaczy być rygorystyczny, konsekwentny i kontrolujący" (za Ostrihanska 2008, s. 257). Ponadto wśród czynników decydujących o efektywnej pracy z podopiecznymi w warunkach probacji prawie co trzeci z badanych kuratorów podkreślił rolę „,wiedzy i doświadczenia” (26\%), a co drugi docenił „częste kontakty i wsparcie” udzielane osobie dozorowanej.

Na wyżej wymienione aspekty decydujące o efektywnej pracy z osobami dozorowanymi szczególną uwagę zwracają nie tylko społeczni, ale także zawodowi kuratorzy sądowi, którzy poza posiadanym doświadczeniem życiowym i udzielaną bezpośrednią pomocą podopiecznym i ich rodzinom, podkreślają rolę i znaczenie zdolności empatycznych i komunikacyjnych oraz umiejętność nawiązania współpracy z instytucjami profilaktyczno-prewencyjnymi (Witkowska-Paleń 2008, s. 108; Wójcik 2010, s. 235; Gogacz 2012, s. 156).

Należy jednak pamiętać, że doświadczenie w pracy z osobami dozorowanymi jest pochodną długości stażu wykonywanej służby społecznej, a ten w przypadku badanych kuratorów nie był zbyt imponujący i wynosił przeciętnie tylko ok. 7 lat. Ponadto dla $14 \%$ badanych skutecznym oddziaływaniom resocjalizacyjnym 
sprzyjać będzie umiejętne operowanie przykładem własnym. Zastosowanie metody wzoru osobowego może mieć szczególne, edukacyjne i terapeutyczne znaczenie $\mathrm{w}$ pracy z dozorowanym z problemem alkoholowym. Nawiązując do tego nurtu rozważań, Zdzisław Kosyrz wyodrębnił wzór „odważnego wychowawcy”, którego cechuje nieustraszoność w obronie wartości związanych $\mathrm{z}$ afirmacją człowieczeństwa, żywa wyobraźnia, szczerość i otwartość w stosunkach międzyludzkich oraz odpowiedzialność moralna jako wyraz dojrzałości psychospołecznej (1997, s. 251).

Myśląc o wzorze idealnego kuratora mamy na uwadze określony zespół cech właściwych z punktu widzenia efektywności sprawowanych dozorów. Wśród nich należy w szczególny sposób doceniać takie, które ułatwiają komunikację z osobą dozorowaną i mogą stanowić przykład godny do naśladowania. Lista takich cech może być bardzo długa, ale do najważniejszych należą: kompetencja i pomysłowość, dążenie do perfekcji, porządku, dokładności czy wiarygodności, zdolność do dokonywania wyborów, umiejętność komunikacji interpersonalnej, taktowność, zdolności do autoanalizy i przyjmowania informacji zwrotnych (Debesse 1988, t. 2, s. 194; Węgliński 2004, s. 72 i n.). Niektóre z tych cech mogą mieć charakter wrodzony (talent pedagogiczny), inne mogą zostać nabyte w procesie kształcenia czy samokształcenia (Kosyrz 1997, s. 11).

Z kolei Mieczysław Łobocki był przekonany, że to nie poszczególne cechy osobowości pedagoga decydują o skuteczności oddziaływań wychowawczych, ale ich układ w połączeniu z konkretną działalnością pedagogiczną. To dopiero połączenie wybranych cech niezbędnych $\mathrm{w}$ pracy wychowawczej z konkretnymi zadaniami i indywidualnością pedagoga tworzą konstelację, która może warunkować powodzenie oddziaływań wychowawczych (1974, s. 165). Istotne jest to, aby poszczególne cechy wraz z nabywanym doświadczeniem pedagogicznym przekształcały się w określone postawy wychowawcze i preferowany styl pracy wychowawczej pedagoga. Ciągle też kuratorom i pedagogom resocjalizacyjnym należy przypominać koncepcję wychowawcy spolegliwego, opracowaną przez Tadeusza Kotarbińskiego (1967, s. 68 i n.). Postawa pedagoga spolegliwego sprowadza się do preferowania przez wychowawcę kilku podstawowych zachowań wobec podopiecznego, są to: życzliwość, skłonność do pomagania, wrażliwość na potrzeby, dobroć, udzielanie niezawodnego oparcia, sprawiedliwe traktowanie i odważna obrona interesów wychowanka.

W postawach wychowawczych pedagogów resocjalizacyjnych nieodzowne jest manifestowanie zachowań świadczących o ofiarności i poszanowaniu podopiecznego. Konieczne są zachowania nacechowane prawością, sprawiedliwością, prawdomównością, dotrzymywaniem słowa, co znacznie wzmacnia wiarygodność wychowawcy w oczach podopiecznych. Ponadto w pracy z młodzieżą niepełnosprawną czy przestępczą niejednokrotnie konieczne jest ujawnianie męstwa osobistego. 
W bezpośrednich oddziaływaniach wychowawczych liczy się także wytrwałość i skuteczność działania, a także opanowanie i dyscyplina wewnętrzna (Węgliński 2004, s. 75).

Skuteczne wykonywanie zadań resocjalizacyjnych jest zdecydowanie łatwiejsze wtedy, gdy kurator może wychowywać osobę dozorowaną bez stosowania przymusu, posługując się wzorem osobowym i autorytetem zdobytym i potwierdzonym w odczuciach i postawie podopiecznych, na co szczególną uwagę zwracał Zbigniew Tyszka już na początku lat 60. XX wieku (1963). Natomiast Józef Czesław Babicki wybitny przedstawiciel klasyki pedagogiki opiekuńczej okresu międzywojennego - wysunął tezę, że autorytet jest naturalnym skutkiem pewnych cech posiadanych przez wychowawcę. Do cech tworzących rdzeń osobowości wychowawcy zaliczał: „młodość ducha, prostotę, takt, subtelność, obiektywizm, cierpliwość, szybkość orientacji, jasność sądu, prostolinijność, szczerość itd.” (1933, s. 94).

Tymczasem Otton Lipkowski - wybitny pedagog specjalny - analizując walory charakterologiczne i osobowe pedagogów, w sposób szczególny podkreślał, że autorytet, uznanie, zaufanie osiąga pedagog przez kompetencje i umiejętności prawidłowego rozpoznawania sytuacji wychowawczych. Od pedagoga specjalnego oczekiwał postawy gotowości do niesienia pomocy, życzliwości i uznania niepowtarzalnej wartości każdego człowieka (1992, s. 217). To, że badani kuratorzy zwrócili uwagę na szczególne znaczenie wzoru i autorytetu w pracy z osobą dozorowaną jest szczególnie ważne i godne podkreślenia. Kurator sądowy musi potwierdzać swój autorytet nie tylko przez posiadane cechy i kompetencje, ale także przez status, pełnioną funkcję czy doświadczenie zawodowe (Robertis 1996, s. 200).

Należy jednak pamiętać, że o tym, czy kurator jest osobą znaczącą wychowawczo, czy posiada określony autorytet wychowawczy, przesadzają odczucia podopiecznych, a nie pozytywna samoocena kuratorów. Chcąc lepiej przekonać się, jak badani kuratorzy postrzegają swoją rolę w pracy z osobami dozorowanymi, poproszono respondentów o dokończenie następującego zdania: „Kurator w toku oddziaływań resocjalizacyjnych to...”.

Dla badanych kurator w oddziaływaniach resocjalizacyjnych to przede wszystkim „nauczyciel-wychowawca” (34\%) oraz „opiekun i powiernik” (30\%). Tylko co piąta osoba postrzega kuratora jako kontrolującego zachowanie podopiecznego „przedstawiciela sądu” (20\%). Jeżeli do tej listy dodamy to, że 16\% respondentów wskazało kuratora jako „osobę posiadającą autorytet u podopiecznych”, to ostrożnie można stwierdzić, że badani kuratorzy społeczni przede wszystkim aspirują do roli wychowawcy korygującego postawy i zachowania osób dozorowanych, a nie urzędnika sądowego „inwigilującego” skazanych. Tylko tak postrzegający swoją rolę kuratorzy będą w stanie sprostać oczekiwaniom ustawodawcy zawartym w art. 1 u.k.s., gdzie zapisano, że kuratorzy realizują zadania o charakterze 
wychowawczo-resocjalizacyjnym. Wykonywanie tych merytorycznych zadań w istotny sposób odróżnia kuratora od zwykłego urzędnika zajmującego się czynnościami administracyjnymi i biurowymi na terenie sądu.

W dalszej części badań postanowiono kuratorów społecznych przed kolejnym problemem, polegającym na próbie określenia, jakie są oczekiwania stawiane przed kuratorem sądowym, na czym może polegać ich „misja”, a nawet „powołanie” do wykonywania zadań statutowych w ramach tej szczególnej służby społecznej. Kuratorzy kończyli następujące zdanie: „Od kuratora należy oczekiwać...”.

Z uzyskanych odpowiedzi wynika, że społeczni kuratorzy sądowi, myśląc o swoich zobowiązaniach, przede wszystkim deklarują „zaangażowanie i pomoc w rozwiązywaniu problemów podopiecznych” (28\%) oraz dążenie do „nawiązania dobrego kontaktu z dozorowanym i jego rodziną" (22\%). W wykonywaniu zadań statutowych chcą być „konsekwentni” (16\%), a także pragną stanowić „dobry przykład" i wzór do naśladowania dla podopiecznych (14\%).

W modelu mieszanym, zawodowo-społecznym, praca kuratorów „dobrowolnych" jest formą współdziałania społeczeństwa z wymiarem sprawiedliwości. Z badań amerykańskich wynika, że model służb kuratorskich, ale też ich status i funkcjonowanie uzależnione są od jasno określonych przez ustawodawcę koniecznych do zrealizowania zadań i czynności oraz od dostrzeganych przez kuratorów oczekiwań formułowanych przez kierowników zespołów służby kuratorskiej, osoby nadzorujące ich pracę z ramienia sądu czy opinię społeczną (Paparozzi, Demichell 2010). Kurator sądowy jako kompetentny pracownik szczególnej służby społecznej podczas wykonywania zadań statutowych nie może zapominać o tym, że poziom i zakres zastosowanej kontroli nad podopiecznymi musi być wprost proporcjonalny do podejmowanych i realizowanych oddziaływań reedukacyjnych, korekcyjnych i wychowawczych. W opiniach badanych kuratorów społecznych można odnaleźć motyw służebności wobec osób dozorowanych i ich rodzin, a także dążenie do postawienia się w roli autorytetu i osoby znaczącej wychowawczo dla podopiecznych.

\section{PODSUMOWANIE}

Zgodnie z formalnymi zaleceniami Organizacji Narodów Zjednoczonych zawartymi $\mathrm{w}$ „regułach minimalnych dotyczących środków alternatywnych wobec pozbawienia wolności" (regułach tokijskich) celem oddziaływań probacyjnych jest udzielenie osobie dozorowanej wszechstronnej pomocy psychologicznej, społecznej i materialnej, wzmacnianie więzi ze społecznością lokalną oraz zmniejszenie prawdopodobieństwa ponownego popełnienia przestępstwa. W autopercepcji badanych społecznych kuratorów sądowych uwidoczniony został proces 
dojrzewania i krystalizowania się poczucia przynależności do szczególnej służby społecznej, która może w przyszłości sprostać zadaniom wynikającym z profesjonalnego modelu probacji. Dlatego należy domagać się, aby w proponowanych rozwiązaniach metodycznych resort sprawiedliwości w sposób bardziej krytyczny podchodził do rozwiązań organizacyjnych wynikających z procedury zarządzania przypadkiem (case management). Rola kuratora sądowego nie może zostać zredukowana do wykonywania czynności prewencyjno-kontrolnych, ograniczonych często do informowania sądu o tym, która $\mathrm{z}$ osób dozorowanych może z dużym prawdopodobieństwem popełnić $\mathrm{w}$ przyszłości kolejny akt kryminalny.

Przeciwnicy rozwiązań metodycznych opartych na zarządzaniu ryzykiem zwracają uwagę na nadmierne koncentrowanie się w ocenie pracy kuratorów na wskaźniku powrotu osób dozorowanych na drogę przestępstwa, co może prowadzić do zaniechania oddziaływań wychowawczych i schematycznego wykluczania skazanych $\mathrm{z}$ funkcjonowania w środowisku otwartym.

Walcząc o jakość oddziaływań wychowawczych kuratorów sądowych, nie można zaakceptować rozwiązań metodycznych, które są całkowicie sprzeczne z celami i zasadami probacji rozumianej jako szczególnej służby społecznej. Należy przede wszystkim koncentrować się na poszukiwaniu rozwiązań systemowych i organizacyjnych, które umożliwią kuratorom podejmowanie i pełną realizację zadań utożsamianych z modelem klinicznym (wychowującym) kurateli, wzbogaconym o określoną ofertę edukacyjną, pomocową i reintegracyjną, realizowaną z udziałem osób dozorowanych i znaczących reprezentantów społeczności lokalnej.

\section{LITERATURA}

Ambrozik W., 2009, Postępowanie probacyjne z perspektywy pedagogiki resocjalizacyjnej. „Probacja”, nr 1.

Andrews D.A., Bonta J., 2010, The Psychology of Criminal Conduct. New Providence, Andersen Publishing.

Andrews D.A., Bonta J., 2007, Risk-Need-Responsivity Model for Offender Assessment and Rehabilitation. Ottawa, Public Safety Canada, opublikowano: https:// cpoc.memberclicks.net/assets/Realignment/risk_need_2007-06_e.pdf.

Babicki J.C., 1933, O wychowaniu. „Życie Dziecka”, nr 1.

Bałandynowicz A., 2002, Probacja. System sprawiedliwego karania. Warszawa, Wydawnictwo Kodeks.

Bałandynowicz A., 2011, Destygmatyzacja tożsamości dewiantów jako zmiana czasowa i interpersonalna w polifunkcyjnym modelu probacji. W: A. Kieszkowska (red.), Tożsamość osobowa dewiantów a ich reintegracja społeczna, cz. l. Kraków, Impuls. 
Bałandynowicz A., 2006, Probacja. Resocjalizacja z udziałem społeczeństwa. Warszawa, Wydawnictwo Prawo i Praktyka Gospodarcza.

Bałandynowicz A., 1996, Probacja. Wychowanie do wolności. Grodzisk Mazowiecki, Primum.

Bałandynowicz A., 2009, Probacyjny model kurateli sądowej w Polsce. „Probacja”, nr 3-4.

Bartkowicz Z., 2013, Agresywność, kompetencje społeczne i samoocena resocjalizowanych nieletnich a ich przestępczość w okresie dorosłości. Lublin, Wydawnictwo UMCS.

Beckett Ch., 2010, Podstawy teorii dla praktyków pracy socjalnej. Warszawa, Wydawnictwo Akademii Pedagogiki Specjalnej.

Bley R., 1988, Szkolna pedagogika lecznicza. W: M. Debesse, G. Mialaret (red.), Rozprawy o wychowaniu, t. 1. Warszawa, PWN.

Buksik D., 2003, Wrażliwość sumienia. Studium psychologiczne. Warszawa, Centrum Metodyczne Pomocy Psychologiczno-Pedagogicznej.

Cieślik M., Sijka A., 2004, Humanitarni idioci. „Wprost”, nr 21.

Czapów Cz., 1978, Wychowanie resocjalizujące. Warszawa, PWN.

Davis C., Bahr S., Ward C., 2012, The process of offender reintegration: Perceptions of what helps prisoners reentersociety. "Criminology and Criminal Justice", 13(4), 446-469.

Debesse M., Mialaret G. (red.), 1988, Rozprawy o wychowaniu. Filozoficzne, psychologiczne i socjologiczne aspekty wychowania. Warszawa, PWN.

Fidelus A., 2012, Determinanty readaptacji społecznej skazanych. Warszawa, Wydawnictwo Uniwersytetu Kardynała Stefana Wyszyńskiego.

Filek J., 1984, Pseudowychowanie. „Studia Filozoficzne”, nr 4.

Frankfort-Nachmias Ch., Nachmias D., 2001, Metody badawcze w naukach społecznych. Poznań.

Frysztacki K., 2005, Socjalna Ameryka. O obszarze pomocy społecznej i pracy socjalnej w Stanach Zjednoczonych. Kraków, Wydawnictwo Nomos.

Garwin B.A., Seabury Ch., 1998, Działania interpersonalne w pracy socjalnej: procesy i procedury. Katowice, Śląsk.

Gogacz K., 2012, Różnicowanie oddziaływań resocjalizacyjnych społecznych kuratorów sądowych a efektywność dozorów probacyjnych. Radom, Wyższa Szkoła Handlowa.

Gromek K., 2002, Kuratorzy sadowi. Komentarz do ustawy z 27 lipca 2001. Warszawa, Wydawnictwo Prawnicze LexisNexis.

Gromek K., 2001, Probacja czy kuratela albo środki alternatywne - próba optymalizacji systemu w ujęciu ewolucyjnym. W: B. Cichońska i in. (oprac.) Probacyjne 
środki polityki karnej - stan i perspektywy. Warszawa, Dział Wydawniczy Kancelarii Senatu.

Han-Ilgiewicz N., 1995, Pisma, szkice, artykuty, rozprawy. Zebrał i wstępem poprzedził K. Poznański. Warszawa, Wyższa Szkoła Pedagogiki Specjalnej im. Marii Grzegorzewskiej.

Heine M., 1982, Warunki efektywności resocjalizacji nieletnich poddanych dozorowi sądowych kuratorów społecznych. Wrocław, Wydawnictwo Uniwersytetu Wrocławskiego.

Jadach K., 2011, Praca kuratora sadowego w sprawach rodzinnych, nieletnich $i$ karnych. Poznań, Wydawnictwo Naukowe Uniwersytetu im. Adama Mickiewicza. Jedynak T., Rzepniewski A., Pawlaczyk H., Raport dotyczacy oceny efektywności kuratorskiej stużby sadowej oraz oceny kosztów jej funkcjonowania i szacunkowych kosztów zwiększenia jej efektywności (druk powielony), opublikowany: http:// kurator.webd.pl/.

Jedynak T., Stasiak K., 2008, Komentarz do ustawy o kuratorach sądowych. Warszawa, LexisNexis.

Joubrel H., 1945, L’Enfance dite coupable. Paris, Blond et Gay.

Kalinowski M., 1990, Nadzór kuratora sądowego forma wychowania resocjalizacyjnego. W: K. Pospiszyl (red.), Resocjalizacja nieletnich. Doświadczenia i koncepcje. Warszawa, Wydawnictwa Szkolne i Pedagogiczne.

Kalinowski M., 1984, Vademecum rodzinnego kuratora sadowego. Warszawa, Instytut Wydawniczy Związków Zawodowych.

Kalinowski M., 2003, Zarys dziejów resocjalizacji nieletnich. Warszawa, APS.

Kępka S., 2007, Kuratela sądowa: wychowująca czy kontrolno-represyjna? Ujęcie formalnoprawne. W: E. Bielecka (red.), Profilaktyka i adaptacja społeczna. Białystok, Wydawnictwo Uniwersyteckie.

Komorowski A., 1925, Sądy dla nieletnich w Polsce. „Szkoła Specjalna”, nr 4, 243. Kopeć-Chróścicka M., 1984, Kurator sadowy. Zadania profilaktyczne i resocjalizacyjne. Warszawa, Wyższa Szkoła Pedagogiki Specjalnej im. Marii Grzegorzewskiej.

Kopaliński W., 1968, Słownik wyrazów obcych i zwrotów obcojęzycznych. Warszawa, Wydawnictwo Wiedza Powszechna.

Kosyrz Z., 1997, Osobowość wychowawcy. Warszawa, Agencja Wydawnicza CB.

Kotarbiński T., 1967, Medytacje o życiu godziwym. Warszawa, Wiedza Powszechna. Kwaśniewski J. (red.), 1995, Praca socjalna, pomoc społeczna. Warszawa, Interart. Lalak D., 1995, Teoretyczny i praktyczny sens metody indywidualnych przypadków. W: T. Pilch, L. Lepalczyk (red.), Pedagogika społeczna: człowiek w zmieniajacym się świecie. Warszawa, Wydawnictwo Akademickie Żak. 
Lewicka-Zelent A., 2013, Uwarunkowania gotowości nieletnich do zadośćuczynienia w paradygmacie sprawiedliwości naprawczej. Lublin, Wydawnictwo UMCS.

Lipkowski O., 1992, Osobowość pedagoga specjalnego. „Szkoła Specjalna”, nr 5.

Łobocki M., 1983, Warunki efektywności pracy wychowawczej z dziećmi i młodzieża. W: S. Popek (red.), Prawidłowe i zaburzone funkcjonowanie dzieci i młodzieży w procesie rozwoju i wychowania. Lublin, Wydawnictwo UMCS.

Łobocki M., 1974, Wychowanie w klasie szkolnej. Warszawa, Wydawnictwa Szkolne i Pedagogiczne.

Łukaszewski W., 1983, Czynniki decydujące o powodzeniu wychowania. W: B. Suchodolski (red.), Społeczeństwo wychowujące: rzeczywistość i perspektywy. Wrocław, Zakład Narodowy im. Ossolińskich.

Machel H., 2003, Więzienie jako instytucja karna i resocjalizacyjna. Kraków, Arche. Marzec-Holka K., 1994, Instytucja społecznych kuratorów sądowych w świetle badań. Bydgoszcz, Wydawnictwo Uczelniane WSP.

Miller W.R., 2009, Wzmacnianie motywacji do zmiany w terapii nadużywania substancji. Warszawa, Wydawnictwo PARPAMEDIA.

Ostrihanska Z., 2008, Diagnoza w pracy kuratora sadowego. W: T. Jedynak, K. Stasiak (red.), Zarys metodyki pracy kuratora sadowego. Warszawa, Wydawnictwo Prawnicze LexisNexis.

Ostrihanska Z., Greczuszkin A., 2000, Praca z indywidualnym przypadkiem w nadzorze rodzinnego kuratora sadowego. Lublin, Norbertinum.

Paparozzi M., Demichelle M., 2010, Amerykańskie stużby probacji i warunkowego zwolnienia. Stan przeciążenia, niezrozumienia czy niedocenienia. „Probacja”, nr 1 .

Paparozzi M., Gendreau, P., 2005, An intensive supervision program that worked: service delivery, professional orientation, and organizational supportiveness. "Prison Journal", 85, 445-466.

Pilch T., Bauman T., 2001, Zasady badań pedagogicznych. Warszawa, Żak.

Porowski M., 2007, Kuratela sądowa w koncepcjach polityki kryminalnej. W: E. Bielecka (red.), Profilaktyka i adaptacja społeczna. Białystok, Wydawnictwo Uniwersyteckie Trans Humana.

Pytka L., 2013, Ekskluzja versus inkluzja w pedagogice resocjalizacyjnej. "Journal of Modern Science", nr 1.

Pytka L., 2000, Pedagogika resocjalizacyjna. Warszawa, Wydawnictwo Akademii Pedagogiki Specjalnej im. Marii Grzegorzewskiej.

Pytka L., 2010, Readaptacja jako element polityki reintegracji społecznej. W: L. Pytka, B.M. Nowak (red.), Problemy wspótczesnej resocjalizacji. Warszawa, Pedagogium, Wyższa Szkoła Pedagogiki Resocjalizacyjnej. 
Pytka L., 2008, Rozkwit pedagogiki resocjalizacyjnej w Polsce. „Opieka. Wychowanie. Terapia”, nr 3-4.

Pytka L., 1986, Sukces i porażka w resocjalizacji. „Szkoła Specjalna”, nr 1.

Robertis C., 1996, Metodyka działania w pracy socjalnej. Katowice, PWN.

Sawicka K., 2001, Probacyjne środki w profilaktyce i resocjalizacji nieletnich. W:

B. Cichońska (oprac.) Probacyjne środki polityki karnej-stan i perspektywy. Warszawa, Dział Wydawniczy Kancelarii Senatu.

Sawicka K., 1985, Projekt modelu organizacyjnego kurateli sądowej. „Zeszyty Naukowe Instytutu Badania Prawa Sądowego", nr 23.

Skidmore R.A., Thackeray M.G., 1998, Wprowadzenie do pracy socjalnej. Katowice, PWN.

Stępniak P., 1998, Wymiar sprawiedliwości i praca socjalna w krajach Europy Zachodniej. Poznań, Ławica.

Sztuka M., 2013, Anachronizm i aktualność. Idea resocjalizacji w sporze o nowoczesność. Kraków, Wydawnictwo Uniwersytetu Jagiellońskiego.

Szymanowski T., 2003, Działalność kuratorów sądowych w pierwszym pótroczu 2002 r. w świetle wyników badań. W: J. Lipski, A. Chodyra (red.), Kurator w społeczeństwie obywatelskim. Warszawa, Kancelaria Sejmu.

Śliwerski B., 2010, Teoretyczne i empiryczne podstawy samowychowania. Kraków, Oficyna Wydawnicza Impuls.

Tyszka Z., 1963, Rola kuratora sądowego w resocjalizacji nieletnich przestępców. Poznań, Uniwersytet im. A. Mickiewicza.

Utrat-Milecki J., 2010a, Etos pracy kuratora sądowego. W: P. Zieliński (red.), 90 lat kurateli sądowej w Polsce. Historia - teraźniejszość - przyszłość. Warszawa, Biuro Analiz Sejmowych, Kancelaria Sejmu.

Utrat-Milecki J., 2010, Kara. Teoria i kultura penalna: perspektywa integralnokulturowa. Warszawa, Wydawnictwa Uniwersytetu Warszawskiego.

Utrat-Milecki J., 2006, Podstawy penologii. Teoria kary. Warszawa, Wydawnictwa Uniwersytetu Warszawskiego.

VanBenschoten S., 2008, Risk needs Assessment: Is This the Best We Can Do?. "Federal Probation", nr 72 (2).

Veillard-Cybulsky M i H., 1968, Nieletni przestępcy w świecie. Warszawa, PWN.

Ward D., Scott J., Lacey M., 2002, Probation: Working for Justice. Oxford, Oxford University Press.

Węgliński A., 2004, Development of the court tutorage in Poland. W: R. Kucha (red.), European Integration Through Education. Lublin, Maria Curie-Skłodowska University.

Węgliński A., 2004, Mikrosystemy wychowawcze w resocjalizacji nieletnich. Lublin, AWH Antoni Dudek. 
Węgliński A., 2013, Pedagogiczne uwarunkowania resocjalizacji nieletnich w ośrodkach kuratorskich. W: Z. Bartkowicz, A. Wojnarska, A. Węgliński (red.), Efektywność resocjalizacji nieletnich $w$ warunkach wolnościowych. Lublin, Wydawnictwo UMCS.

Węgliński A., 2008, Skuteczność i jakość oddziatywań wychowawczych w warunkach nadzorów kuratorskich. W: I. Pospiszyl (red.), Sukcesy i porażki poprawiania niepoprawnych. Kielce, Wszechnica Świetokrzyska.

Węgliński A., 2007, Wartości ogólnoświatowej służby społecznej a oddziaływania resocjalizacyjne $w$ warunkach wolności nadzorowanej w Polsce. W: M. Chepil, R. Kucha (red.), Europejska wspólna przestrzeń edukacyjna a przeobrażenia oświatowe w Polsce i na Ukrainie 1989-2006. Nadzieje i zagrożenia. Drohobycz-Lublin, Oddział Redakcyjno-Wydawniczy Państwowego Uniwersytetu Pedagogicznego im. Iwana Franki w Drohobyczu.

Węgliński A., 2010, Wizerunek pedagogiczny sądowych kuratorów rodzinnych. W: Z. Bartkowicz, A. Węgliński, A. Lewicka (red.), Powinności i kompetencje $w$ wychowaniu osób niedostosowanych społecznie. Lublin, Wydawnictwo UMCS.

Węgliński A., 2015, Zasoby osobiste społecznych kuratorów sądowych niezbędne w przezwyciężaniu zaburzeń w przystosowaniu dozorowanych $z$ problemem alkoholowym. W: A. Bałandynowicz, E. Jówko, K. Marciniak-Paprocka (red.), Edukacja inkluzyjna. Konteksty indywidualistyczne, wspólnotowe i transpersonalne, cz. 2. Siedlce, Wydawnictwo Uniwersytetu Przyrodniczo-Humanistycznego.

Witkowska-Paleń A., 2008, Instytucja społecznego kuratora sądowego w opinii osób petniących funkcje kuratora. Stalowa Wola, Katolicki Uniwersytet Lubelski Jana Pawła II.

Wójcik D. i in., 2010, Kuratela sądowa: sukcesy i porażki. Warszawa, Wydawnictwo Naukowe Scholar.

Wójcik D., 1999-2000, Probacja - rozwiązania prawne w niektórych krajach europejskich. „Archiwum Kryminologii”, t. XXV.

Wójcik D., 2012, Stosowanie w postępowaniu karnym narzędzi diagnostyczno-prognostycznych służących oszacowaniu ryzyka powrotności do przestępstwa. Warszawa.

Zagórski J. (red.), 2008, Wykonywanie środków probacji i readaptacji skazanych $w$ Polsce. Warszawa, Biuro Rzecznika Praw Obywatelskich. 


\title{
SELF-PERCEPTION OF DIRECT RESOCIALIZATION \\ TREATMENT BY COURT-APPOINTED GUARDIANS
}

\begin{abstract}
The article evaluates the ways of resocialization treatment by court-appointed guardians. The theoretical introduction contains a short analysis of the mixed model of probation for adults and determinant factors of resocialization activities in the work with people whose criminal derailment is connected with risk factors and alcohol-related problems. In the empirical part the self-perception of direct resocialization treatment by court-appointed guardians is presented. The information is unique in the context of current one-way analyses of the work of court-appointed guardians based mainly on the evaluation of entries in worksheets filled by the guardians themselves.
\end{abstract}

Keywords: probation, probationers, methods of resocialization education 